\title{
MANAJEMEN PEMBELAJARAN AKTIF BERBASIS WEBSITE PADA ERA REVOLUSI INDUSTRI 4.0
}

\author{
Rudi Hartono1) dan Resti Yetyastuti ${ }^{2)}$ \\ 1)Universitas Negeri Jakarta, Jakarta \\ rudihartono_mp16s3@mahasiswa.unj.ac.id \\ 2)Universitas Djuanda, Bogor \\ restiyektyastuti@gmail.com
}

\begin{abstract}
Abstrak
Penelitian ini bertujuan untuk melakukan pengelolaan pembelajaran aktif berbasis website pada era revolusi industri 4.0. Pengelolaan yang dilakukan meliputi perencanaan pembelajaran, pengorganisasian pembelajaran, pengimplementasian pembelajaran, pengontrolan pembelajaran, pengevaluasian pembelajaran serta faktor pendukung dan penghambat. Pengelolaan pembelajaran aktif dilaksanakan di SMK Negeri 2 Argamakmur Bengkulu Utara. Metode yang digunakan dalam penelitian ini adalah deskriptif kualitatif. Dengan penerapan manajemen pembelajaran aktif berbasis website di sekolah ini, terlihat siswa/i dapat dengan mudah mendapatkan materi dan informasi baik yang ada di dalam sekolah maupun yang di luar sekolah. Proses manajemen dapat berjalan dengan sangat baik ketika adanya penerapan berbasis website. Proses manajemen menjadi lebih cepat, akurat dan terukur dalam perencanaan, pengorganisasi, pengimplementasian, pengontrolan dan pengevaluasian.
\end{abstract}

Kata Kunci: manajemen, pembelajaran aktif, website, revolusi industri 4.0

\begin{abstract}
This study aims to manage website-based active learning in the era of industrial revolution 4.0. The management includes learning planning, organizing learning, implementing learning, controlling learning, evaluating learning, supporting and inhibiting factors. The management of active learning was carried out in SMK Negeri 2 Argamakmur, North Bengkulu. The method used in this study is descriptive qualitative. With the implementation of website-based active learning management in this school, it can be seen that students can easily get material and information both inside and outside the school. The management process can run very well when there is a website-based implementation. The management process is faster, more accurate and measurable in planning, organizing, implementing, controlling and evaluating.
\end{abstract}

Keywords: management, active learning, website, 4.0 industrial revolution

\section{PENDAHULUAN}

Perkembangan teknologi informasi dan komunikasi telah menjanjikan potensi besar dalam mengubah cara seseorang fbelajar, memperoleh informasi, menyesuaikan informasi dan sebagainya. Teknologi informasi dan komunikasi menyediakan peluang bagi pendidik untuk mengembangkan teknik pembelajaran sehingga menghasilkan hasil yang baik. Demikian juga bagi pelajar dengan teknologi informasi dan komunikasi diharapkan mereka dapat lebih mudah untuk menentukan dengan apa dan bagaimana siswa untuk dapat menyerap informasi secara cepat dan efisien. Teknologi pembelajaran merupakan satu himpunan dari proses terintegrasi yang melibatkan manusia, prosedur, gagasan, peralatan, dan organisasi serta pengelolaan cara-cara pemecahan masalah pendidikan yang terdapat di dalam situasi belajar yang memiliki tujuan dan disengaja (Sudjana, 2001 : 13). Inovasi di bidang teknologi terutama teknologi informatika telah mengubah wajah dunia pendidikan dari sistem korespondensi menjadi sistem pembelajaran apa yang dikenal dengan istilah belajar jarak jauh (Mufti, 2012 : 4). Guru sebagai pengelola pembelajaran harus mengemas pembelajaran yang efektif dan bermakna bagi siswa. Pembelajaran aktif akan memiliki makna, jika pembelajaran yang dikemas guru dapat dinikmati oleh 
siswa dan dapat memotivasi siswa. Setya Yuwana Sudikan (2004: 2) menegaskan, mengajar menggunakan TIK adalah menata kegiatan belajar di kelas agar pembelajaran dapat aktif dan memiliki motivasi dalam menggali makna serta menghargai ketidakseragaman

Implementasi pendidikan dalam bentuk pembelajaran di sekolah-sekolah atau perguruan tinggi sarat sekali dengan informasi yang harus diolah para pembelajar dan pengajar sehingga menjadi sesuatu yang bermakna. Ditinjau dari pihak pembelajar seberapa banyak, seberapa penting dan menarik informasi tersebut sehingga dapat menjadi sesuatu yang bermakna.

Ditinjau dari pihak pengajar bagaimana informasi tersebut disajikan atau disampaikan sehingga pembelajar dapat dengan mudah menerimanya. Di sinilah teknologi informasi akan memegang peranan yang sangat penting bagaimana mengolah bahan ajar sebagai bentuk informasi sehingga menarik, mudah diterima dan setiap peserta didik memiliki kesempatan yang sama untuk mendapatkannya.

Pemanfataan teknologi informasi dan komunikasi dalam pendidikan sangat erat kaitannya dengan penggunaan computer, TV, radio dan perangkat keras lainnya. Munculnya teknologi dunia maya melalui internet telah menyemarakkan dan menyempurnakan komunikasi. Salah satu masalah yang dihadapi dunia saat ini yaitu usaha peningkatan mutu pendidikan. Mutu pendidikan sebagai salah satu pilar sumber daya manusia yang sangat penting maknanya bagi pembangunan nasional. Pada akhirnya seluruh rangkaian tersebut akan mengubah sekolah di indonesia menjadi institusi pembelajaran yang kreatif dan dinamis antara guru dan murid-murid menjadi suatu pembelajaran aktif yang lebih termotivasi, memiliki rasa ingin tahu, kreatif, dan tidak bergantung pada satu pemahaman. TIK dalam hal ini adalah suatu perangkat yang terdiri dari perangkat keras (hardware) dan perangkat lunak (software) dengan dukungan multimedia dapat menyajikan sebuah tampilan berupa teks nonseksual, non liniear, dan multi dimensional dengan percabangan tautan dan simpel secara interaktif.

Proses belajar mengajar di SMK Negeri 2
Argamakmur Kabupaten Bengkulu Utara masih tergolong monoton yaitu dengan menggunakan metode konvensional meskipun sudah melakukan beberapa perubahan dibeberapa mata pelajaran dalam menggunakan layanan TIK. Namun hal ini masih dirasakan kurang karena kurangnya kreatifitas dan antusias guru dalam memberikan sentuhan inovasi didalam pembelajaran yang ada sehingga murid menjadi tidak memiliki kreatifitas dalam melakukan pembelajaran. Permasalahan ini muncul bukan hanya karena kemampuan dan motivasi belajar siswa yang kurang, tetapi juga faktor lingkungan belajar yang kurang mendukung. Dalam hal ini kreativitas guru dalam menggunakan TIK untuk mengelola pembelajaran mempunyai pengaruh yang sangat besar dalam meningkatkan hasil belajar siswa.

\section{TINJAUAN PUSTAKA}

Manajemen menurut Dessler (2003 : 236) yaitu usaha untuk meningkatkan prestasi manajemen dengan menanamkan pengetahuan, perubahan perilaku, atau peningkatan keterampilan. Tentu saja sasaran akhirnya adalah untuk menguatkan prestasi perusahaan itu dimasa depan. Proses manajemen terdiri dari (1) menilai kebutuhan strategis perusahaan (misalnya, untuk mengisi lowongan eksekutif mendatang, atau untuk mendorong sifat kompetitif), (2) menilai prestasi manajer, dan kemudian (3) mengembangkan manajer (dan calon manajer).

Manajemen menurut Pidarta ( 2004 : 4) yaitu dalam pendidikan dapat diartikan sebagai aktivitas memadukan sumbersumber pendidikan agar terpusat dalam usaha mencapai tujuan pendidikan yang ditentukan sebelumnya.

Manajemen menurut Daft ( 2002 : 2), di definisikan sebagai pencapaian sasaransasaran organisasi dengan cara efektif dan efesien melalui perencanaan, pengorganisasian, kepemimpinan dan pengendalian sumber daya manusia pada sebuah organisasi.

Manajemen menurut Sclan dan Key dalam Danim (2003 : 164) mendefinisikan sebagai proses pengkoordinasian dan pengintegrasian semua sumber baik manusia, fasilitas, maupun sumber daya 
teknikal lain untuk mencapai berbagai tujuan khusus yang ditetapkan.

Manajemen menurut Bafadal (2003 : 39) yaitu proses kerja melalui penggunaan sumber daya manusia dan fasilitasnya untuk mencapai tujuan organisasi secara efisien. The Liang Gie dalam Mahatika (2006 : 6) menyatakan bahwa manajemen adalah semua perbuatan untuk mengerahkan kelompok orang atau menggerakan segala fasilitas dalam suatu kerjasama untuk mencapai tujuan tertentu.

Berdasarkan pernyataan d iatas maka dapat disimpulkan bahwa apa yang dimaksud dengan manajemen adalah sebuah proses atau kegiatan yang memiliki perencanaan yang disusun dengan baik adanya pengorganisasian disetiap lini, adanya pengimplemntasian dari rencana yang telah disusun, kemudian melakukan evaluasi dari tahapan-tahapan yang ditempuh serta adanya faktor pendukung dan penghambat.

Pembelajaran aktif (active learning) adalah suatu pembelajaran yang mengajak peserta didik untuk belajar secara aktif. Ketika peserta didik belajar dengan aktif, berarti mereka yang mendominasi aktifitas pembelajaran. Mereka secara aktif menggunakan otak mereka baik untuk menemukan ide pokok dari materi pelajaran, memecahkan persoalan atau mengaplikasikan apa yang baru mereka pelajari ke dalam suatu persoalan yang ada dalam kehidupan nyata (Hisyam, 2008:16).

Belajar aktif meliputi berbagai cara untuk membuat siswa aktif sejak awal melakukan aktivitas-aktivitas yang membangun kerja kelompok dan dalam waktu yang singkat membuat mereka berpikir tentang materi pelajaran (Silberman,1996:6).

Pembelajaran aktif merupakan suatu bentuk pembelajaran yang memungkinkan siswa berperan secara aktif dalam proses pembelajaran baik dalam bentuk interaksi sesama siswa maupun siswa dengan pengajar pada proses pembelajaran aktif tersebut (Machmudah, 2008:12).

Pembelajaran aktif adalah proses internal peserta didik dengan tenaga pendidik dan sumber belajar pada suatu lingkungan belajar (Undang-undang RI No.20 : 2003). Pembelajaran mengacu pada segala kegiatan yang dirancang dan didukung oleh segala lini dalam proses belajar mangajar yang melibatkan peserta didik dan tenaga pendidik, adanya interaksi anatara individu dengan sumber belajar yang memiliki komponen, materi, proses dan evaluasi yang saling berkaitan (Panen, 2003 : 7). Tujuan manajemen pembelajaran aktif adalah dapat diartikan Jadi pembelajaran aktif adalah suatu model pembelajaran yang membuat siswa menjadi aktif, siswa diajak menyelesaikan masalah dengan menggunakan pengetahuan yang mereka miliki dan menerapkan apa yang telah mereka pelajari. Aspek-aspek yang mempengaruhi terkait dengan manajemen pembelajaran yang disusun guru meliputi proses perencanaan, pengorganisasian, pengimplementasian, evaluasi pembelajaran aktif, dan faktor pendukung dan penghambat. Penguasan materi yang dimiliki oleh guru menentukan keberhasilannya didalam menyampaikan pelajaran yang berbasis pada TIK (Teknologi Informasi dan Komunikasi). Proses belajar mengajar serasa menyenangkan dan terkesan tidak membosankan terhadap apa yang sedang dipelajari guru bisa lebih kreatif dan inovatif terhadap materi yang disampaikan kepada para siswa.

Pembelajaran berbasis TIK (Teknologi Informasi dan Komunikasi) yang dapat berjalan dengan baik dan lancar akan memiliki pengaruh besar terhadap kemampuan siswa dalam memahami dan mengimplementasikan apa yang disampaikan oleh guru beberapa diantaranya adalah meningkatkan kualitas belajar mengajar, memeperluas ilmu pengatahuan yang ada, mendorong siswa dan guru untuk selalu berpikir kritis terhadap kondisi pendidikan yang ada, memotivasi siswa dan guru untuk dapat kreatif dan inovatif, meningkatkan pengetahuan terhadapa kebijakan yang akan diambil, mengurangi kekurangan pemahaman pada bidang Teknologi Informasi dan Komunikasi.

Teknologi Informasi dan Komunikasi (TIK) memiliki dua fungsi utama yang digunakan dalam kegiatan pembelajaran yaitu meliputi: 1) Teknologi berfungsi sebagai alat (tool), yaitu alat bantu bagi pengguna (user) atau siswa untuk membantu pembelajaran, misalnya dalam mengolah kata, mengolah angka, membuat unsur grafis, membuat database, membuat program administratif untuk siswa, guru, dan staf, data 
kepegawaian, keuangan, dan sebagainya; 2) TIK (Teknologi Informasi dan Komunikasi) berfungsi sebagai ilmu pengetahuan (science).

Dalam hal ini TIK (Teknologi Informasi dan Komunikasi) sebagai bagian dari disiplin ilmu yang harus dikuasai oleh siswa, misalnya dalam pembelajaran di sekolah sesuai kurikulum 2006 terdapat mata pelajaran TIK sebagai ilmu pengetahuan yang harus dikuasai siswa semua kompetensinya. Di dalam pembelajaran aktif berbasis TIK dapat dikelompokan menjadi beberapa bagian diantaranya adalah (1) Memiliki perencanaan yang baik dan matang didalam materi yang ingin disampaikan kepada para siswa meliputi banyak hal dianataranya guru harus mengenal apa yang dimaksud dengan teknologi informasi dan komunikasi, guru mampu merancang bahanbahan ajar yang akan digunakan, guru mampu menggunakan media pendukung pada pembelajaran aktif berbasis TIK; (2) Memiliki keterkaitan satu dengan lainya dalam artian antara guru dan siswa memiliki sinergi saling mengisi satu sama lain guna meciptakan suasana pembelajaran aktif berbasis TIK (Information and Communication Techonlogy) yang menyenangkan; (3) Memiliki tujuan yang jelas dari apa yang telah dirumuskan secara bersama-sama pada model pembelajaran aktif berbasis TIK (Information and Communication Techonlogy).

\section{METODE PENELITIAN}

Penelitian kualitatif adalah penelitian tentang riset yang bersifat deskriptif dan cenderung menggunakan analisis dengan pendekatan induktif. Proses dan makna (perspektif subyek) lebih ditonjolkan dalam penelitian kualitatif. Landasan teori dimanfaatkan sebagai pemandu agar fokus penelitian sesuai dengan fakta di lapangan. Selain itu landasan teori juga bermanfaat untuk memberikan gambaran umum tentang latar penelitian dan sebagai bahan pembahasan hasil penelitian. Terdapat perbedaan mendasar antara peran landasan teori dalam penelitian kuantitatif dengan penelitian kualitatif.

Di dalam penelitian kuantitatif, penelitian berangkat dari teori menuju data, dan berakhir pada penerimaan atau penolakan terhadap teori yang digunakan; sedangkan dalam penelitian kualitatif peneliti bertolak dari data, memanfaatkan teori yang ada sebagai bahan penjelas, dan berakhir dengan suatu "teori".

Penelitian kualitatif jauh lebih subyektif dari pada penelitian atau survei kuantitatif dan menggunakan metode sangat berbeda dari mengumpulkan informasi, terutama individu, dalam menggunakan wawancara secara mendalam dan grup fokus. Sifat dari jenis penelitian ini adalah penelitian dan penjelajahan terbuka.

Penelitian kualitatif (Qualitative research) bertolak dari filsafat konstruktivisme yang berasumsi bahwa kenyataan itu berdimensi jamak, interaktif dan suatu pertukaran pengalaman sosial (a shared social eperience) yang diinterpretasikan oleh individu-individu. (Nana Syaodih, 2001 : 94).

Menurut Sugiono( 2009 : 15) metode penelitian kualitatif adalah metode penelitian yang berlandaskan pada filsafat postpositifsime, digunakan untuk meneliti pada kondisi objek yang alamiah (sebagai lawannya adalah eksperimen) dimana peneliti adalah sebagai instrument kunci, pengambilan sample sumber dan data dilakukan secara purposive dan snowbaal, teknik pengumpulan data dilakukan dengan triangulasi (gabungan) analisis data bersifat induktif / kualitatif, dan hasil penelitian kualitatif lebih menekankan pada makna daripada generalisasi. dalam penelitian ini terdapat beberapa pihak yang di anggap penting oleh peneliti untuk menjadi subjek diantaranya adalah Kepala SMK Negeri 2 Argamakmur Kabupaten Bengkulu Utara, bagian sarana dan prasarana, bagian kurikulum, kepala tata usaha, beberapa guru dan siswa yang memiliki peluang yang sama dalam subjek penelitian pada saat peneliti turun ke lapangan. 
Tabel 1.1 Responden Penelitian

\begin{tabular}{|c|c|c|}
\hline Responden & Jumlah & Informan \\
\hline 1. Kepala Sekolah & 1 orang & 1 orang \\
\hline 2. Sarana dan Prasarana & 1 orang & 1 orang \\
\hline 3. Kurikulum & 1 orang & 1 orang \\
\hline 4. Kepala TU & 1 orang & 1 orang \\
\hline 5. Guru & 70 orang & 10 orang \\
\hline 6. Siswa & 612 orang & 15 orang \\
\hline Jumlah & 686 & 29 orang \\
\hline
\end{tabular}

Alasan memilih responden yang ada di atas karena (1) kepala sekolah adalah secara akademik bertindak sebagai seorang pemimpin sekaligus manager tertinggi di SMK Negeri 2 Argamakmur Kabupaten Bengkulu utara. Kepala sekolah bertanggung jawab penuh atas segala kejadian yang ada di ruang lingkup akademik; (2) Wakil kepala sekolah bidang sarana prasarana merupakan bagian terpenting didalam proses penunjang belajar mengajar di SMK Negeri 2 Argamakmur Kabupaten Bengkulu utara; (3) Wakil kepala sekolah bidang kurikulum merupakan bagian terpenting dalam hal tentang data dan informasi kesiswaan yang ada di SMK Negeri 2 Argamakmur Kabupaten Bengkulu utara; (4) Kepala tata usaha adalah pihak yang mengurus bagian administrasi secara keselurahan di SMK Negeri 2 Argamakmur Kabupaten Bengkulu utara; (5) Guru meruapakan bagian terpenting didalam penelitian ini karena guru bertindak sebagai pelaksana dalam proses belajar mengajar aktif berbasis TIK ; (6) Siswa adalah bagian terpenting dari beberapa sumber penelitian yang menjadi penerima dan melakukan umpan balik (feed back) dari proses belajar mengajar aktif berbasis TIK yang ada di SMK Negeri 2 Argamakmur Kabupaten Bengkulu utara. Pada penelitian ini digunakan beberapa cara di dalam pengumpulan data yaitu diantaranya observasi, survey, wawancara dan dokumentasi. Teknik observasi digunakan untuk mengetahui proses manajemen sebelum dan sesudah menggunakan wbsite. Teknik dokumentasi sebagai pelengkap dalam pengumpulan data karena data dokumentasi yang diambil berupa dokumen pendukung seperti data nilai, data pelaksanaan pembelajaran, dan administrasi sekolah. Adapun data yang diambil pada subjek penelitian adalah data yang memiliki hubungan dengan manajemen pembelajaran aktif berbasis TIK (Information and Communication Technology) di SMK Negeri 2 Argamakmur. tahapan analisa data digunakan dalam penelitian ini terdiri dari tiga alur kegiatan yang terjadi secara bersamaan yaitu reduksi data, penyajian data dan vervikasi yang merupakan siklus interaktif, sehingga diperoleh jawaban dari masalah yang diteliti.

1. Data Reduction (Reduksi Data)

Reduksi data berarti merangkum, memilih hal yang pokok, memfokuskan pada hal yang penting, dicari pola dan temanya. Dalam penelitian ini penulis memasuki area SMK Negeri 2 Argamakmur Kabupaten Bengkulu Utara sebagai tempat penelitian. maka dalam meraduksi data peneliti akan memfokuskan pada penerapan pembelajaran berbasis TIK baik dari guru dan siswa yang memiliki kecerdasan tinggi berdasarkan data nilai hasil belajar per semester dengan mengkatagorikan pada aspek penyampaian materi, pemanfaatan TIK sebagai gaya belajar, perilaku sosial, interalsi dengan keluarga dan lingkungan.

2. Data Display (penyajian data)

Data display berarti mendisplay data yaitu menyajikan data dalam bentuk uraian singkat tentang pembelajaran berbasis TIK di SMK Negeri 2 Argamakmur, perancangan pembelajaran, hubungan antar katagori, dan lain-lain. Menyajikan data yang sering digunakan dalam penelitian kualitatif adalah bersifat naratif. Ini dimaksudkan untuk memahami apa yang terjadi di lapangan meliputi penyajian data masalah: (a) Bagaimana perencanaan pembelajaran aktif berbasis TIK di SMK Negeri 2 Argamakmur; (b) pengorganisasian pembelajaran aktif; (c) Pelaksanaan Pembelajaran; (d) evaluasi pembelajaran; (e) faktor pendukung dan penghambat dalam pembelajaran berbasis TIK di SMK Negeri 2 Argamakmur yang selanjutnya akan di pahami oleh peneliti.

3. Penarikan kesimpulan (Conclusion Drawing / Verification) 
Langkah terakhir dari model ini adalah penarikan kesimpulan dan verifikasi dari pembelajaran berbasis TIK di SMK Negeri 2 Argamakmur. Kesimpulan dalam penelitian ini mungkin dapat menjawab rumusan masalah yang dirumuskan sejak awal namun juga tidak, karena masalah dan rumusan masalah dalam penelitian pembelajaran berbasis TIK di SMK Negeri 2 Argamakmur masih bersifat sementara dan berkembang .setelah peneliti ada di lapangan. Kesimpulan dalam penelitian yang ada di lapangan merupakan temuan baru yang sebelumnya belum ada yang berupa deskripsi atau gambaran yang sebelumnya belum jelas menjadi jelas dapat berupa hubungan kausal / interaktif dan hipotesis / teori.

\section{HASIL DAN PEMBAHASAN}

1. Perencanaan pembelajaran aktif merupakan proses utama dalam inovasi perencanaan dalam kegiatan yang akan dilaksanakan. Tanpa perencanaan yang baik, maka suatu kegiatan yang sudah ada tidak akan dapat berjalan dangan baik. perencanaan yang dimaksud yaitu perencanaan dalam pembelajaran aktif berbasis teknologi informasi dan komunikasi yang harus relevan dengan materi pembelajaran yang sudah berjalan dan sesuai aturan yang ditetapkan oleh dinas pendidikan dan kebudayaan sehingga sejalan dengan visi dan misi sekolah. Hasil wawancara dengan salah seorang guru sebagai berikut:

"Dalam mengembangkan materi yang sudah dipersiapkan atau memberikan inovasi dalam materi yang sudah dipersiapkan sebelumnya khusunya materi pembelajaran yang sesuai dengan visi dan misi sekolah maka pada pertemuan selanjutnya akan saya sampaikan kepada siswa, saya selalu mengembangkan perencanaan apa yang relevan dengan materi yang akan saya sampaikan pada pertemuan selanjutnya supaya tidak terkesan monoton dan tidak membosankan, biasanya saya sebagai seorang tenaga pendidik memberikan keleluasaan kepada siswa untuk mencari materi-materi yang akan dibahas pada pertemuan selanjutnya di internet dimana topik pembahasan materi telah saya tentukan pada pertemuan sebelumnya, sehingga ketika proses belajar mengajar siswa sudah membaca dan memahami topik pembahasan materi yang akan disampaikan oleh tenaga pendidik".

Perencanaan yang sudah dilaksanakan adalah kecocokan dengan topik pembahasan materi atau relevan dan sesuai dengan visi dan misi sekolah dan sesuai dengan topik pembahasan materi yang akan diberikan kepada peserta didik, tenaga pendidik melihat dan memahami topik pembahasan materi terlebih dahulu sebelum menyampaikan baru dapat menentukan cara ataupun metode apa yang akan digunakan dalam proses belajar mengajar supaya lebih menyenangkan.

2. Pengorganisasian pembelajaran aktif adalah suatu kegiatan yang memiliki peran penting dalam pembagian kerja untuk pelaksanaan pembelajaran aktif berbasis teknologi informasi dan komunikasi, tidak seluruh kegiatan pembelajaran menggunakan teknologi informasi dan komunikasi, tetapi dengan teknologi informasi dan komunikasi yang lainnya juga bisa asalkan sesuai dengan materi yang akan disampaikan. Hasil wawancara dengan kepala sekolah sebagai beirikut:

"ya, memang betul dalam pelaksanaan pembelajaran aktif perlunya adanya pembagian tugas dimana ditujukan untuk mempermudah kerja masing-masing sektor. Pihak sekolah sudah mempersiapkan berbagai tugas berdasarkan masing-masing porsinya"

Pengorganisasian pembelajaran aktif yang baik tentunya memiliki banyak orang yang terlibat didalam perumusannya.

3. Pelaksanaan pembelajaran aktif berbasis teknologi informasi dan komunikasi dapat dilaksanakan dimana 
saja, yang terpenting yaitu adanya aliran listrik, koneksi jaringan intranet atau internet, kemudian siswa dapat melihat dan menggunakan fasilitas yang sudah disediakan kapan saja dan dimana saja. Hasil wawancara dengan salah seorang siswa sebagai berikut:

"kami sebagai siswa sangat senang dan bangga di zaman perkembangan teknologi informasi dan komunikasi pada saat ini kami masih dapat mengikutinya khususnya dalam hal pembelajaran aktif berbasis teknologi informasi dan komunikasi, disamping kami mudah menggunakanya, kami juga dapat mudah menjangkaunya, kami juga dapat dengan bebas mengakses materi-materi pembelajaran yang kami butuhkan dalam proses belajar mengajar, kami sangat senang dalam mempelajari materi-materi yang disajikan melalui jaringan intranet dan internet "

Dengan sangat mudahnya peserta didik di sekolah dapat mengunjungi situs-situs dalam mencari materi pembelajaran dan menggunakan fasilitas yang sudah disediakan, hal itu dapat memberi keleluasaan kepada peserta didik dalam mengunjungi dan menggunakanya, hal ini menuntut kemampuan seorang tenaga pendidik dalam memberikan situs-situs website dan memberikan fasilitas yang sudah disediakan kepada peserta didik.

4. Monitoring pembelajaran aktif berbasis aktif adalah sesuatu kegiatan yang sangat penting untuk dilaksanakan, hal ini ditujukan untuk mengukur seberapa efektif teknologi informasi dan komunikasi yang ada di sekolah berperan dalam proses belajar mengajar. Hasil wawancara dengan salah seorang guru di sekolah, adalah sebagai berikut:

"kegiatan monitoring adalah suatu kegiatan yang sangat penting untuk dilaksanakan, kenapa? karena tidak semua teknologi informasi dan komunikasi yang digunakan dalam pembelajaran aktif dapat berjalan dengan baik, terkadang terdapat kendala-kendala diluar dugaan yang terjadi di lapangan, sehingga tujuan pembelajaran belum bisa tercapai dengan baik"

Pemanfaatan teknologi informasi dan komunikasi dalam pembelajaran aktif perlu diadakan monitoring, sehingga dengan adanya kegiatan monitoring ini, tenaga pendidik dapat mengukur tingkat kemampuan nya dalam pemnfaatan teknologi informasi dan komunikasi, sehingga tenaga pendidik dapat memperbaikinya dan mencari strategistrategi untuk menyelesaikannya, sehingga dalam pemanfaatan teknologi informasi dan komunikasi dapat berjalan dengan baik dan semestinya.

5. Evaluasi pembelajaran aktif adalah suatu kegiatan yang sangat penting untuk dilaksanakan, hal ini untuk mengukur apakah pembelajaran aktif berbasis teknologi informasi dan komunikasi dapat berjalan dengan baik. Hasil wawancara dengan salah seorang guru di sekolah adalah sebagai berikut:

"ya, evaluasi, adalah suatu kegiatan yang sangat penting untuk dilaksanakan, karena tidak semua pembelajaran aktif berbasis teknologi informasi dan komunikasi dapat digunakan, kadang-kadang-kadang terdapat banyak kendala di lapangan untuk melaksanakan pembelajaran aktif berbasis teknologi informasi dan komunikasi tersebut, sehingga tujuan pembelajaran tidak tercapai".

Pemanfaatan teknlogi informasi dan komunikasi yang digunakan dalam pembelajaran aktif perlu dilakukan evaluasi, sehingga dengan kegiatan evaluasi ini, guru sebagai tenaga pendidik dapat mengetahui kelemahankelemahan dari pelaksanaan pembelajaran aktif berbasis teknologi informasi dan komunikasi, sehingga bisa cepat mengatasainya dan mencari strategi-strategi yang harus diterapkan untuk pembelajaran aktif, sehingga untuk kedepanya tidak terjadi lagi keselahan-kesalahan dan tujuan pernbelajaran tercapai dengan baik. Hasil wawancara dengan kepala sekolah 
adalah sebagai berikut:

"ya seorang guru sebagai tenaga pendidik wajib melakukan evaluasi dalam pelaksanaan dan penerapan pembelajaran aktif berbasis teknologi informasi dan komunikasi di sekolah dengan hal ini guru sebagai tenaga pendidik bisa mengetahui apa saja kekurangan-kekurangan dalam menggunakan teknologi informasi dan komunikasi dalam pembelajaran aktif tersebut, dengan harapan dapat diperbaiki pada pertemuan selanjutnya".

Kegiatan evaluasi adalah kegiatan untuk mengetahui sampai dimanakah keefektifan dan efisiensi penggunaan teknologi informasi dan komunikasi dalam pembelajaran aktif dapat menunjang kegiatan pembelajaran.. Hasil wawancara dengan salah seorang guru di sekolah yakni sebagai berikut:

"dalam melakukan evaluasi kegiatan peserta didik dalam pembelajaran aktif berbasis teknlogi informasi dan komunikasi terkadang kondisi di lapangan menunjukan perbedaan dengan rencana dan pelaksanaan awal pembelajaran aktif dimana beberapa peserta didik lebih cenderung tidak melakukan pembelajaran seperti dengan bermain game pada saat saat sekolah. sebagai orang tua ketika siswa bereada di sekolah kami guru sebagai tenaga pendidik masih perlu melakukan banyak cara untuk mengatasi kegiatan-kegiatan yang tidak dapat berjalan dengan baik, begitupun juga orang tua menjadi pendidik di rumah bagi siswa".

Peran orang tua sangat diharapkan dalam mengevaluasi prilaku anaknya sebagai peserta didik di rumah, kemajuan teknologi disamping dapat berdampak positif kepada siswa juga dapat berdampak negatif bagi siswa sebagai peserta didik, hal ini tergantung kepada pembinaan, baik itu pembinaan pendidkan di rumah tangga dan didukung oleh pembinaan di sekolah.

6. Faktor pendukung dan penghambat pembelajaran aktif. Dalam pelaksanaan pembelajaran aktif berbasis teknologi informasi dan komunikasi terdapat faktor pendukung dan, faktor penghambat adalah fasilitas dan kesedian sumber daya yang handal dalam menggunakan teknologi informasi dan komunikasi. Hasil wawancara dengan kepala sekolah yakni sebagai berikut:

"dalam melaksanakan pembelajaran aktif berbasis teknologi informasi dan komunikasi tentunya banyak terdapat kendala atau hambatan-hambatan di lapangan, antara lain dukungan fasilitas dan kesediaan sumber daya manusia dalam memanfaatkannya" .

Faktor-faktor penghambat dan kendala tersebut perlu dicarikan solusi, sehingga program penerapan media pembelajaran aktif berbasis teknologi informasi dan komunikasi dapat berjalan dengan baik.

\section{Pembahasan}

1. Perencanaan merupakan langkah awal dalam penerapan pembelajaran aktif berbasis teknologi informasi dan komunikasi. Dengan perencanaan yang baik, seluruh kegiatan yang akan dilaksanakan tentunya akan dapat berjalan dengan baik dan sesuai denga apa yang telah direncanakan. Perencanaan tidak lain merupakan kegiatan untuk menetapkan tujuan yang akan dicapai beserta cara-cara untuk mencapai tujuan tersebut. Sebagaimana dikemukan oleh Sudjana (2006: 16) menyatakan bahwa perencanaan adalah proses yang sistematis dalam pengambilan keputusan tentang tindakan yang akan dilakukan pada waktu yang akan datang.

Hal senada juga dikemukakan oleh Nawawi (1983 : 16) bahwa perencanaan berarti menyusun langkah-langkah penyelesaian suatu masalah atau pelaksanaan suatu pekerjaan yang terarah pada pencapaian tujuan. Dalam hal ini perencanaan mencakup rangkaian kegiatan untuk menentukan tujuan umum (goal) dan tujuan khusu (objektivitas) suatu organisasi atau lembaga penyelenggara pendidikanm berdasarkan dukungan informasi yang 
lengkap. Setelah tujuan ditetapkan perencanaan berkaitan dengan penyusunan pola, rangkaian, dan proses kegiatan yang akan dilakukan untuk mencapai tujuan tersebut. Singkatnya efektifitas perencanaan berkaitan dengan penyusunan rangkaian kegiatan untuk mencapai tujuan, dapat diukur dengan terpenuhinya fakor kerjasama perumusan perencanaan, program kerja dan upaya implementasi program kerja tersebut dalam mencapai tujuan.

Sedangkan pembelajaran aktif menurut Duffy dan Rohler (1989 : 13) bahwa pembelajaran aktif adalah suatu usaha yang sengaja melibatkan dan menggunakan pengetahuan professional yang dimiliki guru untuk mencapai tujuan kurikulum. Pendefinisian gabungan situasi seeara baik, yang meliputi unsur sumber daya manusia, sumber daya alam, dan sumber daya modal. Merumuskan kegiatan yang akan dilaksanakan seeara jelas dan tegas.

Hal senada dikemukakan pula oleh $\mathrm{T}$. Hani Handoko (1995) bahwa terdapat empat tahap dalam pereneanaan, yaitu : (a) menetapkan tujuan atau serangkaian tujuan; (b) merumuskan keadaan saat ini; (e) mengidentifikasi segala kemudahan dan hambatan; (d) mengembangkan reneana atau serangkaian kegiatan untuk peneapaian tujuan.

Pada bagian lain, Indriyo Gito Sudarmo dan Agus Mulyono (1996) mengemukakan bahwa atas dasar luasnya eakupan masalah serta jangkauan yang terkandung dalam suatu perencanaan, maka pereneanaan dapat dibedakan dalam tiga bentuk, yaitu : (1) reneana global yang merupakan penentuan tujuan seeara menyeluruh dan jangka panjang, (2) reneana strategis merupakan reneana yang disusun guna menenrukan rujuan-tujuan kegiatan atau tugas yang mernpunyai ani strategis dan mernpunyai dimensi jangka panjang, dan (3) reneana operasional yang merupakan reneana kegiatan-kegiatan yang berjangka pendek guna menopang peneapaian tujuan jangka panjang, baik dalam pereneanaan global maupun pereneanaan strategis.
Pereneanaan strategi akhir-akhir ini menjadi sangat penting sejalan dengan perkembangan lingkungan yang sangat pesat dan sangat sulit diprediksikan, seperti perkembangan teknologi yang sangat pesat. pekerjaan manajerial yang semakin kompleks, dan percepatan perubahan lingkungan eksternal lainnya. Pada bagian lain, T. Rani Handoko memaparkan secara ringkas tentang langkah-langkah dalam penyusunan perencanaan strategik, sebagai berikut:

Penentuan misi dan tujuan, yang mencakup pernyataan umum ten tang misi, falsafah dan tujuan. Perumusan misi dan tujuan ini merupakan tanggung jawab kunci manajer puncak. Perumusan ini dipengaruhi oleh nilainilai yang dibawakan manajer. Nilai-nilai ini dapat mencakup masalah-masalah sosial dan etika, atau masalah-masalah umum seperti macam produk atau jasa yang akan diproduksi atau cara pengoperasian perusahaan.

profil perusahaan, yang mencerminkan kondisi internal dan kemampuan perusahaan dan merupakan hasil analisis internal untuk mengidentifikasi tujuan dan strategi sekarang, serta memerinci kuantitas dan kualitas sumber daya-sumber daya perusahaan yang tersedia. Profil perusahaan menunjukkan kesuksesan perusahaan di masa lalu dan kemampuannya untuk mendukung pelaksanaan kegiatan sebagai implementasi strategi dalam pencapaian tujuan di masa yang akan datang.

Analisa lingkungan eksternal, dengan maksud untuk mengidentifikasi caracara dan dalam apa perubahanperubahan lingkungan dapat mempengaruhi organisasi. Disamping itu, perusahaan perlu mengidentifikasi lingkungan lebih khusus, seperti para penyedia, pasar organisasi, para pesaing, pasar tenaga kerja dan lembaga-lembaga keuangan, di mana kekuatan-kekuatan ini akan mempengaruhi secara langsung operasi perusahaan.

Meski pendapat di atas lebih menggambarkan perencanaan strategik dalam konteks bisnis, namun secara esensial konsep perencanaan strategik 
ini dapat diterapkan pula dalam konteks pendidikan, khususnya pada tingkat persekolahan, karena memang pendidikan di Indonesia dewasa ini sedang menghadapi berbagai tantangan internal maupun eksternal, sehingga membutuhkan perencanaan yang benarbenar dapat menjamin sustanabilitas pendidikan itu sendiri.

2. Pengorganisasian pembelajaran aktif berbasis teknologi informasi dan komunikasi

Kegiatan pengorganisasian adalah suatu kegiatan yang memiliki peran penting dalam pembagian kerja untuk pelaksanaan pembelajaran aktif berbasis teknologi informasi dan komunikasi, tidak seluruh kegiatan pembelajaran menggunakan teknologi informasi dan komunikasi, tetapi dengan teknologi informasi dan komunikasi yang lainnya juga bisa asalkan sesuai dengan materi yang akan disampaikan.

Ernest Dale seperti dikutip oleh T. Hani Handoko mengemukakan tiga langkah dalam proses pengorganisasian, yaitu : (a) pemerincian seluruh pekerjaan yang harus dilaksanakan untuk mencapai tujuan organisasi; (b) pembagian beban pekerjaan total menjadi kegiatankegiatan yang logik dapat dilaksanakan oleh satu orang; dan (c) pengadaan dan suatu mekanisme untuk mengkoordinasikan pekerjaan para anggota menjadi kesatuan yang terpadu dan harmonis.

Lousie E. Boone dan David L. Kurtz (1984) mengartikan pengorganisasian : " ... as the act of planning and implementing organization structure. It is the process of arranging people and physical resources to carry out plans and acommplishment organizational objective".

Dari kedua pendapat di atas, dapat dipahami bahwa pengorganisasian pada dasamya merupakan upaya untuk melengkapi rencana-rencana yang telah dibuat dengan susunan organisasi pelaksananya. Hal yang penting untuk diperhatikan dalam pengorganisasian adalah bahwa setiap kegiatan hams jelas siapa yang mengerjakan, kapan dikerjakan, dan apa targetnya

$$
\text { George R. Terry }
$$
mengemukakan bahwa "Pengorganisasian adalah tindakan mengusahakan hubungan-hubungan kelakuan yang efektif antara orangorang, sehingga mereka dapat bekerja sarna secara efisien, dan memperoleh kepuasan pribadi dalarn melaksanakan tugas-tugas tertentu, dalam kondisi lingkungan tertentu guna mencapai tujuan atau sasaran tertentu" .

\section{Pengorganisasian}

keseluruhan pengelompokan orangorang, alat-alat, tugas, tugas,kewenangan dan tanggung jawab sedemikian rupa sehingga tercipta suatuorganisasi yang dapat digerakkan sebagai suatu kegiatan kesatuan yang telah ditetapkan (Siagian, 1983).

Berkenaan dengan pengorganisasian ini, Hadari Nawawi (1992) mengemukakan beberapa asas dalam organisasi, diantaranya adalah : (a) organisasi hams profesional, yaitu dengan pembagian satuan kerja yang sesuai dengan kebutuhan; (b) pengelompokan satuan kerja hams menggambarkan pernbagian kerja: (c) organisasi harus mengatur pelimpahan wewenang dan tanggung jawab: (li) organisasi harus mencerminkan rentangan kontrol; (e) organisasi harus mengandung kesatuan perintah; dan ( $f$ ) organisasi harus fleksibel dan seimbang.

3. Pelaksanaan pembelajaran aktif berbasis teknologi informasi dan komunikasi

Berdasarkan seluruh rangkaian proses manajemen, pelaksanaan (actuating) merupakan fungsi manajemen yang paling utama. Dalam fungsi perencanaan dan pengorganisasian lebih banyak berhubungan dengan aspek- aspek abstrak proses manajemen, sedangkan fungsi actuating justru lebih menekankan pada kegiatan yang berhubungan langsung dengan orang-orang dalam organisasi.

Dalam hal ini, George R. Terry (1986) mengemukakan bahwa actuating merupakan usaha menggerakkan 
anggota-anggota kelompok sedemikian rupa hingga mereka berkeinginan dan berusaha untuk mencapai sasaran perusahaan dan sasaran anggotaanggota perusahaan tersebut oleh karena para anggota iru juga ingin mencapai sasaran-sasaran tersebut.

Dari pengertian di atas. pelaksanaan \ actuating) tidak lain rnerupakan upaya untuk menjadikan perencanaan menjadi kenyataan, dengan melalui berbagai pengarahan dan pemotivasian agar setiap karyawan dapat melaksanakan kegiatan secara optimal sesuai dengan peran, tugas dan tanggung jawabnya.

Hal yang penting untuk diperhatikan dalam pelaksanan (actuating) ini adalah bahwa seorang karyawan akan termotivasi untuk rnepgerjakan sesuatu jika: (1) merasa yakin akan mampu mengerjakan. (2) yakin bahwa pekerjaan tersebut memberikan manfaat bagi dirinya, (3) tidak sedang dibebani oleh problem pribadi atau tugas lain yang lebih penting, atau mendesak, (4) tugas tersebut merupakan kepercayaan bagi yang bersangkutan dan (5) hubungan antar teman dalam organisasi tersebut harmonis.

4. Monitoring penerapan pembelajaran aktif berbasis teknologi informasi dan komunikasi

Pengawasan (controlling) merupakan fungsi manajemen yang tidak kalah pentingnya dalam suatu organisasi. Semua fungsi terdahulu, tidak akan efektif tanpa disertai fungsi pengawasan. Dalam hal ini, Louis E. Boone dan David L. Kurtz (1984) memberikan rumusan tentang pengawasan sebagai : ". .. the process by which manager determine wether actual operation are consistent with plans".

Sementara itu, Robert J. Mocker sebagaimana disampaikan oleh T. Hani Handoko (1995) mengemukakan definisi pengawasan yang di dalarnnya memuat unsur esensial proses pengawasan, bahwa :

"Pengawasan manajemen adalah suaru usaha sisternatik unruk menetapkan standar pelaksanaan dengan tujuan-tujuan perencanaan, merancang sistem informasi umpan balik, membandingkan kegiatan nyata dengan standar yang telah ditetapkan sebelumnya, menentukan dan mengukur penyimpanganpenyimpangan, serta mengambil tindakan koreksi yang diperlukan untuk menjarnin bahwa semua sumber daya perusahaan dipergunakan dengan cara paling efektif dan efisien dalam pencapaian tujuan-tujuan perusahaan."

Dengan demikian, pengawasan merupakan suatu kegiatan yang berusaha untuk mengendalikan agar pelaksanaan dapat berjalan sesuai dengan rencana dan memastikan apakah tujuan organisasi tercapai. Apabila terjadi penyimpangan di mana letak penyimpangan itu dan bagaimana pula tindakan yang diperlukan untuk mengatasinya.

Selanjutnya dikemukakan pula oleh T. Hani Handoko bahwa proses pengawasan memiliki lima tahapan, yaitu : (a) penetapan standar pelaksanaan (b) penentuan pengukuran pelaksanaan kegiatan; (c) pengukuran pelaksanaan kegiatan nyata; (d) pembandingan pelaksanaan kegiatan dengan standar dan penganalisaan penyirnpangan-penyimpangan; dan (e) pengambilan tindakan koreksi, bila diperlukan.

Fungsi-fungsi manajemen ini berjalan saling berinteraksi dan saling kait mengkait antara satu dengan lainnya, sehingga menghasilkan apa yang disebut dengan proses manajemen. Dengan demikian, proses manajemen sebenarnya merupakan proses interaksi antara berbagai fungsi manajemen.

Dalam perspektif persekolahan, agar tujuan pendidikan di sekolah dapat tercapai secara efektif dan efisien, maka proses manajemen pendidikan memiliki peranan yang amat vital. Karena bagairnana pun sekolah merupakan suatu sistem yang di dalarnnya melibatkan berbagai komponen dan sejurnlah kegiatan yang perlu dikelola secara baik dan tertib. Sekolah tanpa didukung proses manajemen yang baik, boleh jadi hanya akan menghasilkan 
kesemrawutan lajunya organisasi, yang pada gilirannya tujuan pendidikan pun tidak akan pernah tercapai secara semestinya.

Dengan demikian, setiap kegiatan pendidikan di sekolah harus memiliki perencanaan yang jelas dan realisitis, pengorganisasian yang efektif dan efisien, pengerahan dan pemotivasian seluruh personil sekolah untuk selalu dapat meningkatkan kualitas kinerjanya, dan pengawasan secara berkelanjutan.

5. Evaluasi pemebelajaran aktif berbasis teknologi informasi dan komunikasi di SMK Negeri 2 Argamakamur

Evaluasi dapat diartikan sebagai suatu kegiatan yang terencana untuk mengetahui keadaan suatu objek dengan menggunakan instrumen dan hasilnya dibandingkan dengan suatu tolak ukur untuk memperoleh suatu kesimpulan.

Fungsi utama evaluasi adalah menelaah suatu objek atau keadaan untuk mendapatkan informasi yang tepat sebagai dasar untuk pengambilan keputusan

Sesuai pendapat Grondlund dan Linn (1990) mengatakan bahwa evaluasi pembelajran adalah suatu proses mengumpulkan, menganalisis dan menginterpretasi informasi secaras sistematik untuk menetapkan sejauh mana ketercapaian tujuan pembelajaran. Untuk memeperoleh informasi yang tepat dalam kegiatan evaluasi dilakukan melalui kegiatan pengukuran. Pengukuran merupakan suatu proses pemberian skor atau angka-angka terhadap suatu keadaan atau gejala berdasarkan atura-aturan tertentu.

Dengan demikian terdapat kaitan yang erat antara pengukuran (measurment) dan evaluasi (evaluation) kegiatan pengukuran merupakan dasar dalam kegiatan evaluasi.

6. Faktor pendukung dan penghambat pengelolaan media pembelajaran komputer berbasis website

Berdasarkan hasil wawancara dan observasi peneliti dapat dilihat bahwa faktor pendukung dari pembelajaran aktif berbasis teknologi informasi dan komunikasi adalah adanya semangat, motivasi dan kreatifitas siswa sebagai peserta didik dan guru sebagai tenaga pendidik yang cukup kuat untuk melaksanakan program pembelajaran aktif berbasis teknologi informasi dan komunikasi serta adanya faktor penghambatnya adalah kurangnya sarana dan fasilitas yang belum memadai untuk sebuah teknologi informasi dan komunikasi yang berkembang dan ditarnbah lagi dengan masih adanya sumber daya manusia yang belum siap akan penggunaan teknologi.

\section{KESIMPULAN}

Simpulan penelitian secara umum tentang manajemen pembelajaran aktif berbasis teknologi informasi dan komunikasi di SMK Negeri 2 Argamakmur Kabupaten Bengkulu Utara adalah kegiatan yang dimulaii dengan perencanaan, pengorganisasian, pelaksanaan, monitoring dan evaluasi. Pembelajaran aktif berbasis teknologi informasi dan komunikasi tersebut dimulai dengan perencanaan yaitu merencanakan bagian-bagian apa saja yang akan dilakukan selama kegiatan proses belajar mengajar, kemudian pengorganisasian mengelompokkan jenis-jenis kegiatan yang akan dilaksanakan supaya dapat berjalan dengan baik sesuai dengan tujuan pembelajaran aktif. Kegiatan pelaksanaan yang memang harus dilakukan sesuai dengan perencanaan dan pengorganisasian yang sudah ditentukan dan diakhiri dengan kegiatan monitoring dan evaluasi sebagai saran bagi perbaikan-perbaikan kedepannya.

\section{UCAPAN TERIMA KASIH}

Peneliti mengucapkan terima kasih kepada keluarga besar SMK Negeri 2 Argamakmur yang dijadikan sebagai tempat penelitian dan seluruh pihak yang telah mendukung penelitian ini.

\section{DAFTAR PUSTAKA}

Bafadal, I. (2003). Manajemen peningkatan mutu pendidikan sekolah dasar. Jakarta: Bumi Aksara. 
Bogdan R. C., \& Biklen, S. K. (1992). Studi penelitian deskriptif kualitatif. Jakarta: Rineka Cipta.

Budi.

(2000).

Teknologi informasi dan komunikasi sebagai komoditas. Jakarta: Grafindo Cetak.

Daft, R. L. (2002). Manajemen kekuatan organisasi. Yogyakarta: Bhineka Cipta.

Danim, S. (2003). Kekuatan manajemen pembelajaran. Jakarta: Rineka Cipta

Depdiknas. (2003). Pengembangan model pembelajaran aktif. Diakses dari http://www.kemdikbud.go.id/pengembang an-pembelajaran-aktif.html

Dessler, G. (2003). Pengembangan manajemen pembelajaran. Bandung: Aksara Karya

Instruksi Presiden nomor 6/2001. Rencana pengembangan dan implementasi teknologi informasi dan komunikasi di Indonesia. Jakarta: Asa Mandiri.

Hisyam, Z. (2008). Pembelajaran aktif dalam peningkatan mutu pendidikan.

Mukhtar. (2012). Penelitan deskriptif kualitatif. Jakarta: Aksara Karya

Mahatika. (2006). Manajemen peningkatan sumber daya. Jakarta: Aksara Karya

Machmudah, (2008). Perubahan Paradigma Pembelajaran di Sekolah Menengah Kejuruan,

Syaodih, N. (2001). Penelitian kualitatif (Qualitative research). Yogyakarta: Bhineka Karya

Pidarta, M. (2004). Manajemen pendidikan Indonesia. Jakarta: Rineka Cipta

Panen, P. (2003). Belajar dan pembelajaran. Jakarta: Universitas Terbuka.

Silberman, M. L. (1996). Media pembelajaran. Jakarta: PT. Raja Grafindo Persada

Sugiono. (2009). Metode penelitian kualitatif. Jakarta: Aksara Karya

Undang-undang RI No. 20: 2003 tentang proses internal peserta didik dengan tenaga pendidik dan sumber belajar pada suatu lingkungan belajar. 
Hartono \& Yetyastuti / Manajemen Pembelajaran Aktif Berbasis Website pada Era .. . 